\title{
MORPHONOLOGICAL STRUCTURE OF UKRAINIAN VERB BASICS: TYPOLOGICAL ASPECT
}

\section{Demeshko I. M.}

\section{INTRODUCTION}

Modern research on word-forming morphonology should be based not only on the morphemocentric approach, but also on the basis-centric one, which will make it possible to establish rules and causes of morphonological variation of creative bases. The latest scientific attempts are aimed at determining the morphonological classifications of verb bases in the modern Ukrainian language. The word-forming unit illustrates the word-generating activity of the creative word, clearly presents a perspective approach with a retrospective one, provides a complete description of the word-forming processes and morphonological transformations that accompany these processes.

An example of a distributive method of studying the word-forming morphonology of derivatives is the application of new approaches to the study of the morphonological structure of word-forming units with verb roots of different morphonological structure. An essential factor on which the effectiveness of scientific research depends is a well-thoughtout, balanced concept of research, a successful choice of methods and techniques. Since the word-forming morphonology of deverbatives in grammar is insufficiently studied, the method of studying morphonologically marked derivatives also needs to be improved. At the present stage of morphonological analysis it is appropriate to conduct with reliance on word-forming units, in order to identify the wordforming potential, the derivational capacity of generators of different parts of speech.

Thus, analyzing the basic verbs of word-forming units in the Ukrainian language, it is appropriate to take into account the indivisibility and divisibility of verb basis, the final formative basis, the variability of verb bases, morphonological transformations, compatibility with the formant. 


\section{Conceptual principles of word-forming and morphonological analysis of deverbatives}

The study uses linguistic methods based on the fundamentally centric aspect of the study. The main among them were: descriptive method in synchronous and diachronic aspects; method of linguistic description of linguistic facts - for the implementation of a full-fledged inventory and systematization of deverbatives, characteristics of their structural and semantic features in the morphonological aspect; structural method with methods of component, structural-semantic and functionaltranspositional analysis - to determine the morpheme structure, isolation of word-forming means and ways of creating derivatives, establishing directions of word-forming motivation between motivator and motivator, partly etymological method. Descriptive method (analytical-descriptive) serves as a basis for the application of other methods, because it allows you to describe in detail the main properties of the subject. Because its components are the observation of linguistic facts (classification and systematization), generalization, interpretation. The main purpose of the descriptive method is to generalize the facts: to identify paradigmatic and syntagmatic patterns of verb derivatives, word-forming and valence features of deverbatives at the present stage of language development. The method of interpretation, which covers paradigmatic and syntagmatic methods, helped to establish their differential features on the basis of comparison and contrast of morphonological units, and on the basis of common and distinctive features to unite in different morphonological classes. Modeling method - for different-vector characterization of the repertoire of verb representatives of structural distributors in relation to word-forming paradigms and word-forming units, method of identification and transformation, statistical method. Comparative method aimed at identifying typological characteristics of deverbatives of the Ukrainian language. The structural method, represented by the methods of structural-semantic, oppositional analysis, is to distinguish the common between linguistic objects through similarities and differences in the set of morphonological phenomena; modeling method - for the diagnosis of word-forming nests for the presence of differential features; method of component analysis - to identify word-forming paradigms, to distinguish morphonological classes and morphonological types of word-forming nests with a verb vertex, their subtypes and varieties. At different stages of the research the method of quantitative calculations was used - to establish the degree of productivity of word-forming paradigms, the structure of word-forming 
nests, morphonological models and the method of distributive analysis to identify features of compatibility of verb base with derivational means within word-forming paradigm. Systematic study of the word-forming ability of a lexical-grammatical class makes it possible to trace the relationship between the semantic structures of creative and derivative units, to predict the formation of derivatives, to establish an inventory of word-forming means for its explication, to identify systemic relations. motivation, analyze morphonological transformations by combining different types of finals of creative verb bases with word-forming means, reflect the dynamics of the word-forming process, outline the patterns of derivational processes necessitates the creation of a typology of wordforming morphonology based on creative form as a typological act. The description of word-forming morphonology of deverbatives is carried out on the basis of association, taking into account the semantic and connecting properties of word-forming means.

One of the general methods of linguistic research is structural, the main purpose of which is the knowledge of language as a holistic and hierarchical functional structure, the elements and parts of which are connected by a clear system of linguistic relations. The structural method is represented by various methods of synchronous analysis of speech phenomena, among which the most effective for the study of morphonological phenomena is the method of oppositional analysis. The method of prognostic modeling of word-forming units with a basic verb is used to establish the relationship between the creative and the derivative, its word-forming implementation, to determine morphonological transformations in the neolexem: лютосnád objectified action, called a phrase спадає лють: Не так стоїи! Не ті говориш мудри! Не так живеш!.. Класичний лютоспад! (Р. Лук'янчук) ${ }^{1}$; важкотво́рний - важко творити: Ми не будемо зловживати иим визнанням заслуженого словникаря $i$ вченого, але там, де сама мовна стихія підказує, щзо слово важкомовне $i$ важкотворне, доводиться ці слова зацитувати (С. Караванський $)^{2}$.

The creation of a typology of the structural organization of wordforming units with a verb convinces that for the morphonological model of word-forming units are decisive in the structural transformations of

1 Нелюба А., Редько Є. Словотворчість незалежної України. 2012-2016 : словник / укл. А. Нелюба, С. Редько ; заг. ред. А. Нелюби. Харків : Харківське історико-філологічне товариство, 2017. С. 221.

${ }^{2}$ Там само. С. 60. 
specific and typical word-forming paradigms, in morphonological transformations of deverbatives. Morphonological characteristics of the derivative store information about the structural and semantic rearrangements of specific and foreign language bases and the influence on them of the inventory of derivational means inherent in the corresponding word-forming unit. Morphonological modeling of deverbatives of a certain synchronous section will achieve the goal provided that possible morphonological transformations of derivatives are taken into account, allomorphs are established in a certain microsystem; under such conditions, synchrony reflects the dynamics of the system - diachrony. It should be noted that it is necessary to distinguish phonetic alternations from morphonological ones. The degree of derivational and semantic development of the verb base is evidence of the chronology of the top word in the word-forming unit. The proximity of the morphonological structure of the final formative bases of semantically and etymologically inhomogeneous verbs cannot ensure the homogeneity and homogeneity of morphonological behavior in the structure of deverbatives. The visualization of the morphonological factor in the process of word formation makes it possible to study the valence features of the forms of the modern

Ukrainian language. Peculiarities of the organization of the wordforming system should be carried out in the process of studying paradigmatic (in word-forming paradigms) and syntagmatic (morphological transformations in word-forming pairs, series) connections between the elements of this system. The meanings of wordforming means are not isolated from each other. The purpose of the study of syntagmatic connections in word formation is to identify the types of restrictions on the compatibility of morphemes and to establish within the motivated word elements that have semantic, structural, stylistic properties.

The word-forming nest plays a dominant role in the systematization of Ukrainian word-formation, as it clearly traces the patterns of internal mechanism, which is characterized by hierarchical links between other complex units of the word-formation system (word-forming pairs, series and word-forming paradigms). Reconstruction of the basic verbs of word-forming nests makes it possible to correctly determine the direction of word-forming motivation, morphonological type and to establish a morphonological model. The study of current issues of word-forming morphonology in modern linguistics involves a conceptual and theoretical approach, a comprehensive study of different types of 
morphonological changes in the derivation process, developing a methodology using methods of morpheme, word-forming, morphonological, etymological, contextual analysis, method, method, descriptive method in particular distributive analysis, methods of analogy, quantitative method.

The material for the study was more than 2 thousand self-composed word-forming units with a verb with the use of explanatory, dialectal, word-forming, morpheme, etymological dictionaries, more than 300 text units with morphonologically marked deverbatives from the author's file.

At the beginning of the XXI century there are works devoted to the study of morphonological processes in word change and word formation of the Old Ukrainian language of the second half of the XVI-XVIII centuries (N.P. Rusachenko, 2004) ${ }^{3}$, derivational morphology of Russian dialects (O.G. Antipov, 2002) ${ }^{4}$, typological analysis of the morphonology of unrelated languages (ancient Greek, Latin, Germanic languages) (N.I. Danilina, 2012) ${ }^{5}$, Russian morphonological phenomena, morphological variation in word change and word formation $\left(O . V\right.$. Kukushkina, 2016) ${ }^{6}$. At the same time, the question of wordforming morphonology of Ukrainian deverbatives remains open. This determines the relevance of the study of word-forming morphonology of deverbatives in the synchronous aspect with the elements of etymological analysis when using the study of the features of morphonological transformations of word-form units with basic verbs.

M.Yu. Fedurko (2006) ${ }^{7}$ carried out research of the Ukrainian wordforming morphonology of complex units on the material of substantial

3 Русаченко Н.П. Морфонологічні процеси у словозміні та словотворі староукраїнської мови другої половини XVI-XVIII ст. : автореф. дис. ... канд. філол. наук : 10.02.01. Київ, 2004. 20 с.

4 Антипов А.Г. Морфонологическая категоризация словообразовательной формы : автореф. дисс. ... докт. филол. наук : 10.02.01; 10.02.19. Кемерово, 2002. $56 \mathrm{c}$.

5 Данилина Н.И. Морфонологические системы в синхронии и диахронии (на материале неблизкородственных языков) : автореф. дисс. ... докт. филол. наук : 10.02.19. Саратов, 2012. 38 с.

6 Кукушкина О.В. Морфонология современного русского литературного языка : учебник. Москва:Изд-во Московского ун-та, 2016. 337 с.

${ }^{7}$ Федурко М.Ю. Морфонологія відіменникового словотворення в сучасній українській мові : автореф. дис. ... докт. філол. наук : спец. 10.02.01. Київ, 2005. 36 c. 
word-forming units, O.V. Diyak (2006) $)^{8}$ - structural-semantic organization of word-forming nests with roots for metal designation, L.V. Shchyglo (2009) ${ }^{9}$ - structural and semantic features of word-forming units with bases-verbs of verbs with categorical meaning of active movement in modern German, S.Yu. Zharko, I.M. Shpitko $(2011)^{10}$ - structural and semantic features of the word-forming unit with the top word «sea» in Russian, Ukrainian and Slovak languages, G.V. Pristai $(2011)^{11}$ - on the material of adjective word-forming units, L.E. Rybachkivska $(2015)^{12}$ - structure of word-forming units with verbs-onyms in Ukrainian and English languages, V. D. Ponomarenko, O. O. Dudka $(2018)^{13}$ - structural and semantic characteristics of the word-forming unit with the top «Winter».

At the present stage of development of Ukrainian word formation the problem of classification of basic verbs in the word-forming unit is quite acute, which contributes to the morphonological qualification of deverbatives, and forecasting word-forming means that determine the morphonological specifics of word-forming unis with basic verbs, as well as in the creation of new words. Modern research on word-forming morphonology should be based not only on the morphemocentric approach, but also on the basis-centric one, which will make it possible to establish the rules and causes of morphonological variation of creative bases. The latest scientific attempts are aimed at determining the

8 Дияк О.В. Структурно-семантична організація словотвірних гнізд із коренями на позначення металів : автореф. дис. ... канд. філол. наук : 10.02.01. Київ, 2006. 21 с.

${ }^{9}$ Щигло Л.В. Словотвірний потенціал дієслівних основ 3 категоріальним значенням активного руху в сучасній німецькій мові : автореф. дис. ... канд. філол. наук : 10.02.04. Харків, 2009. 22 с.

10 Жарко С.Ю., Шпітько I.M. Структурно-семантичні особливості словотвірного гнізда 3 вершинним словом «море» в російській, українській i словацькій мовах. Актуальні проблеми слов'янської філології. 2011. Вип. XXIV. Ч. 1. С. 475-483.

11 Пристай Г В. Динамічні морфонологічні моделі відприкметникового словотворення : автореф. дис. ... канд. філол. наук : 10.02.01. Івано-Франківськ, 2011. $20 \mathrm{c}$.

12 Рибачківська Л.Є. Структура словотвірних гнізд з вершинами-онімами в сучасній українській та англійській мовах : контрактивний аспект : дис. ... канд. філол. наук : 10.02.17. Київ, 2017. 248 с.

13 Пономаренко В.Д., Дудка О.О. Структурно-семантична характеристика словотвірного гнізда 3 вершиною «Зима». Лінгвістичні дослідження : збірник наук. праць ХНПУ ім. Г.С. Сковороди. 2018. Вип. 48. С. 126-137. 
morphonological classifications of verb bases in the modern Ukrainian language. The word-forming nest illustrates the word-generating activity of the creative word, makes it possible to show a clearly perspective approach with a retrospective one, thus providing a complete description of word-forming processes.

\section{Structural types of verb bases}

The study of word-forming nests with a basic verb makes it possible to distinguish 6 structural types of verb bases:

1. Closed root verb bases (CVC): нес/mu, ïc/mu, й/mu.

2. Closed unstressed suffixal verb bases: пись-м(ó), леж-áк.

3. Open root verb bases (CV): $\partial y^{\prime} / m u$ (дму); $\partial y^{\prime} / m u^{2}$ (дую); жи/mu, cmalmu.

4. Open stressed suffixal verb bases: чит-ач, дубл-ер, корект-и́p (а).

5. The roots of the verb base are built up by the consonant: бu/mu бит-ком, ви/ти - вит-ок, да/ти - дан-ин(а), дода/ти - додат-ок, жи/ти - жив-ець, жил-ець, жи/m'l-ій; жа/ти - жа́m-н(ий), жám-ник; nac/mu-nacm-yx.

6. Consonant verb bases added by the consonant: пересел-ен/ець, обра-н/ець, посла-н/ець, копіюва́-ль/ник, кореспонд-е́н/ціј)(a), рят-ів/ник, пряд-ильн/ик.

Analysis of the root structure of the verb base and formant allowed to determine the following basic morphonological rules: 1. Closed verb bases ending in pairs of hardness - soft consonants, which, depending on the formants, have a hard or soft morphological variant: вод/ú/mu во/д'/-ій, плат/ú/mu - пла/m'/-іжс.

2. Closed verb bases and formants that create incompatible combinations of phonemes on the morpheme seam undergo truncation of the verb base, which is accompanied by alternation of the vocalized variant of the verb base: брес/mú - брод-и́-ти; жа́/mu ${ }^{1}-ж н$-ець, жнив(á); кро́j/i/mu - крій-0; ход/ú/mu - обхо́д-и-ти - обхідник. 3. Open bases have closed extended variants of the root morpheme, accompanied by alternation of the vocalized variant of the verb base: $\sigma \dot{u} / m u^{l}-\sigma i j-\dot{a} \kappa$

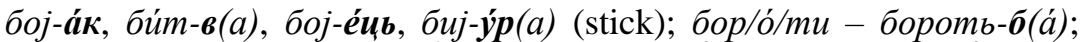
доj/í/mu - ді́й-л(o), дій-ни́к ${ }^{l}$ (cattle), дій-ни́к ${ }^{2}$ (vessel); жá/mu ${ }^{2}$ (68)жом-0, жм-ен'(a). 4. The closed verb base and the formant, which create incompatible combinations of phonemes on the morpheme seam, are truncated by the verb base, which is accompanied by the alternation of the consonant variant of the verb base: берег/mú - береж-ї' $\boldsymbol{H}^{\prime}(a)$, бере́ж-ен(ий), береж-к(и́й), бе́реж-н(ий); біг/ти - біж-енець; 


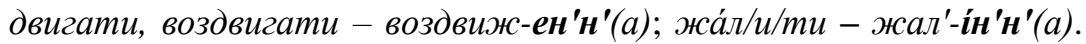
5 . Verbal bases have a stressed variant, having closed extended variants of the root or suffix morpheme: брá/mu, жú/mu, знá/mu, nác/mu; бра́/mu - бра́-нець; да́/mи - да́m-ок; 6. Verbal bases have an unstressed variant, vocal or consonant alternation in the root morpheme: берег/mú, вес/mú, мог/mú, нес/mú, пек/mú, рос/mú, тек/mú, иввіс/mú.

Analysis of the basic verbs of word-forming nests revealed the following patterns: 1) consonant alternations at the base of verbs are predictable, regular, informative; 2) morphonological transformations occur according to certain rules, in clearly defined pairs; 3 ) the degree of regularity, productivity, predictability of consonant alternatives in verb derivatives is different.

For the contact zone at the boundary of root and word-forming morphemes it is necessary to take into account the following parameters: 1) formal divisibility / indivisibility of the creative basis; 2) the organization of the root morpheme; 3 ) class and character of the initial formant. The morphonological qualification of word-forming units is determined by: morphonological structure, morphonological position, morphonological transformation and morphological model. Wordforming nests with basic verbs are divided into morphonological classes and morphonological types based on morphonological transformation, which marks the morphonological structure of derivatives of the corresponding word-forming paradigm and determines the morphonological specifics of each class. The surveyed vertices of wordforming units of verb derivatives are characterized by different categorical-derivational potential of morphonologically marked deverbatives. This made it possible to distinguish morphonological classes and types of open vertex verb bases of word-forming units. All word-forming units with an indivisible verb are divided between 5 morphonological classes ${ }^{14}$ and 7 morphonological classes with a divisible verb, taking into account the nature of the verb base, complex morphonological transformations (consonant or vocal alternations, types of final consonant bases, closed participle, indivisible), increase of root

14 Демешко I.M. Морфонологічні класи словотвірних гнізд із нечленованими вершинними дієсловами в українській мові. Наукові записки. Серія «Філологічні науки». Кропивницький : КОД, 2020. Вип. 187. С. 115-121. 
or suffix morpheme, change of accent positions (shift of emphasis on root or suffix (formative or formant) morpheme) ${ }^{15}$.

\section{Morphonological classifications of verb bases in the Ukrainian language}

It is necessary to analyze the verb verbs of word-forming nests taking into account their morphonological classification of verb-forming bases. For open verb bases is characterized by truncation or extension of root or suffix morphemes. Given the nature of the verb base, the following morphonological types of basic verbs of word-forming nests are distinguished:

1. Indivisible open verb bases: MT-1 (the first morphological type): вити - вит-ок, вит-к(ий); МТ-2: бути - прибути - прибу-ток; МT-3: брати - бра-нець, давати - дава-лець; МТ-4: жити жит-л(о); пити - пит-в (ó);

МТ-5: дути - видути - видимати; МТ-6: грі́ти -грі̀-лк(a); пі́ти $-n i-\boldsymbol{c H}^{\prime}(a)$;

МТ-7: мати -май-н(o); да́ти (dati, davati) - давати - дава́-лець;

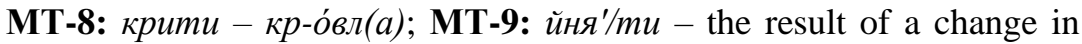
sound form яти (< jęti) (vъn-jęti, съняти < съn-jęti) - вийняти виїм-к(а), прийняти - приймати - прийом-0; МТ-10: мити миј-уч(ий), нити - ниј-уч(ий). МТ-11 -о́-: поло́ти - пол-ен(ий).

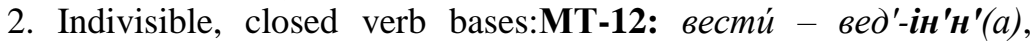
брести́ - бродити, брод'-ін'н' $\boldsymbol{H}^{\prime}(a)$; MT-13 (stressed root morpheme): пря'сти - пряд'-ін'н'(a); МТ-14: мести́ - мет'-іль, плести́ - плет-

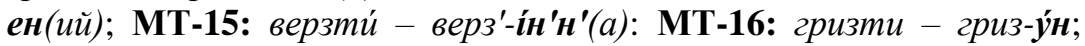
MT-17: nacmu - nacm-yx. The second class includes creative verb bases for sonorous p: M 18: дерти - дер'-íŭ. The third class includes creative

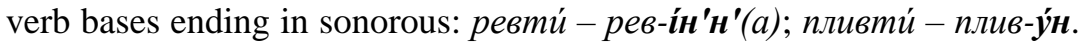
To the fourth - verb bases ending in labial:M 19: гребти́-скреб-óк;

M 20: $с к y ́ б т и ~-~ с к у ́ б а-\boldsymbol{\mu}^{\prime} \boldsymbol{\mu}^{\prime}(a)$. To the fifth - verb bases ending in the posterior $(\boldsymbol{\kappa}, \boldsymbol{x})$ and pharyngeal z: МT-21: могти - мож-лив(ий); МT-22: бігти - біж-енець;

15 Демешко I.M. Морфонологічні класи словотвірних гнізд із членованими вершинними дієсловами в українській мові. Філологічний часопис : збірник наук. праць / гол. ред. О.Ю. Зелінська. Умань : ВПЦ «Візаві», 2020. Вип. 1 (15). C. $38-44$. 
МT-23: волокти - волочити - волоч-і́н'н'(a); МТ-24: ректи - річ-0, відректи - відре́ч-ен'н'(a); сікти - січ-0, січч-ен(ий); текти - тік-0, теч-0 (a) and

MT-25: рости - picm-0.

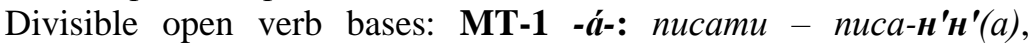
пись-м $(o)$;

МТ-2 -á-: лизати - лиз-ун, лижс-уч(ий); МТ-3 -á-: буяти буя'- $\boldsymbol{H}^{\prime} \boldsymbol{H}^{\prime}(a)$;

МТ-4 -á-: держати - держ-а́к; МТ-5 -á-: ламати - поламати поламл-ен(ий); МТ-6 -á-: зав'язати - зав'язь-0; МТ-7 -á-: пускати -

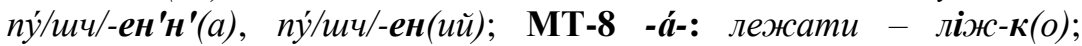
МT-9 -á-: кусати - кус'-ій;

МT-10 -á-: спати - спл'-yx; МТ-11 -a-: вішати - віша-лк $(a)$; читати - чита-лк (a); гадати - гада-лк (a); МТ-12 -а-: жати -жнець, жн'-ій, жменя, падати - пад'-іюж; МТ-13 -а-: плакати - плач-0, пла́ч-уч(ий); МТ-14 -а-: казати - кажк-учи, різати - рі́ж-уч(ий), різ'з'-0(á), різь-б(á); МТ-15 -а-: ві́дати - повідомити - повідомл-

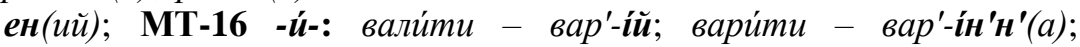
говори́ти - говор'-ін'н'(a); МТ-17 -и́-: носи́ти - нос'-ій, нош-О(a); МТ-18 -и́-: води́ти - водж-ен'н'(a); МТ-19 -и́-: твори́ти - твор'-

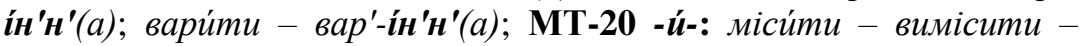
виміш-ен(ий);

МТ-21 -и-: вабити - вабл-ен'н'(a), ва́бл-ен(ий), ва́бл'-ач(ий); МТ-22 -и-: креслити - кресл'-áp; МТ-23 -ú-: графи́ти - гра́фл-

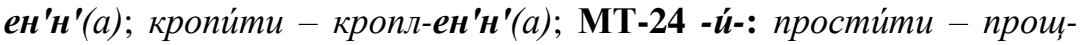
ен(ий); МТ-25 -и-: разити - вразити - вражж-ен(ий); МТ-26 -и-: їздти - ̈̈ждж-ен(ий); МТ-27 -и́- робитти - робл-ен(ий), робо́ч0(uй); МТ-28 -и́-: сади́mи -сад'-ачи; МТ-29 -и́-: роди́mu - за́pid-0, заро́дж-ен'н'(a); будйти - бу́дж-ен'н'(a); вали́ти - перевали́ти, перева́л'л'-(*j)(a); МТ-30 -и́- корити - покорити - покір-лив(ий); МТ-31 -и́-: спокусити - спокуш-ен(ий); МТ-32 -и́-: переселити пересел-енець; точити - точи-лк(a); МТ-33 -и́-: журити - журб(a); МТ-34 -и-: зи́чити - пози́чити - по́зик-0 $(a)$; МТ-35 -и-: радити - рад-0(a); МТ-36 -í-: хотіти - хоті-н'н'(a); МТ-37 -í-: вертіти - верт-и́н; МТ-38 -í-: висіти - віш-а́к; МТ-39 -í-: летіти підлетіти -підлі́т-0; МТ-40 -í-: кипіти - кипл'-ач(ий); МТ-41 -о-: кроїти - крій-0; МТ-42 -ý-: гну́ти - гну-т(ий), згинати - згин-0; МТ-43 ý-: прагнути - прагн-ен'н'(a); МТ-44 -ну-: киснути - кисл(ий) - кис'-і́ль ; МТ-45 -c-: n'я'сти́ (144) - n'я'-льщ'(a); МТ-46 -ува́-: віншувати - віншува́-н'н'(a), диктува́ти - дикт-а́нт, інформувати 
- інформ-а́mор; МТ-47 -ува́-: абстрагува́ти - абстра́к-цї(а), претендувати - прете́нз'-ij(a).

In morphonological types (MT), dominant autoaccent strong suffix morphemes are distinguished. For zero-suffix deverbatives formed from verbs with the thematic suffix $\boldsymbol{- a}-\boldsymbol{-}, \boldsymbol{u}-$, the stress is recessive (in the initial syllable of the accent unity, the prefix morpheme is emphasized): за́пис, пере́каз, ви́віз, за́рід, ви́пуск, ви́бір, but нака́з, дороговка́з, відва́p, добір, забір, перебір.

Thus, in the Ukrainian language word-forming nests with a basic verb are divided into morphological types, which take into account the indivisibility / divisibility of basic verbs of word-forming units. Established with divisible basic verbs - 47 morphological types. The surveyed vertices of word-forming units of verb derivatives are characterized by different categorical-derivational potential of morphologically marked deverbatives.

\section{Morphonological classifications of indivisible open verb bases in the Ukrainian language}

Open verb bases are divided into two types - indivisible and divisible. Indivisible verb bases are characterized by the growth of root or suffix morphemes. For divisible verb bases - truncation of the

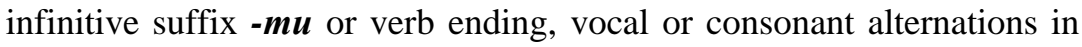
the root morpheme. Suffix verb bases increase predictability of morphonological type and emphasis positions. The type of the final consonant helps to establish a set of variants of the verb base, alternation on the morpheme seam, features of transfer of emphasis from the base to inflection or to previous syllables - prefix or root morpheme. Most Ukrainian verb bases are open root suffix bases of the infinitive. Indivisible verb bases in the Ukrainian language undergo the truncation or consonant increase of root or suffix morphemes when adapting the verb base to the formant. For an open indivisible verb base (MT: $\kappa p u ́ / m u$ ) characteristic increase of the root morpheme by the consonant $(\boldsymbol{B})$, changes in the base before the suffix $*_{-j}-($ в $>$ вл') (крівля, покрівля), жи/ти, ni/mи - жи-вець, пі-вень, кра́n/a/mu - кра́пля (пј > пл'). In divisible specific verbs (MT: платúmu, проплати́mи - про-пла́ч$e н(u \check{u}))$ there is a consonant alternation, shifting the emphasis to the root morpheme. For derivatives MT: жá/mu characteristic alternations in the root morpheme (V//0, $\mathrm{C} / / \mathrm{C}^{\prime}$ (morphonological position of palatalization)): жá/mu ${ }^{1}-$ жá-m(uй), жн'-ій, до-жámu ${ }^{1}$, дожин-а́-ти - дожи́н-0. In divisible borrowed verbs 
(MT: дубл'/ува́/mи (11 derivatives)) - дублюва́ти-ся, дубл'-ás, дубл-е́р, дубле́р-ськ(ий), про-дублюва́ти characteristic alternations in the root morpheme $\left(\mathrm{C}^{\prime} / / \quad \mathrm{C}\right.$ (morphonological position of depalatalization)).

Morphonological analysis of verb bases involves their word-forming behavior in the derivative. When creating deverbatives of substantive and adjectival blocks, the following specifics are in the stressed position.

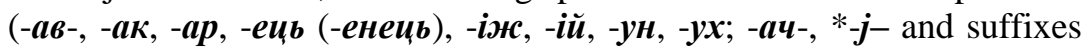
of foreign origin (-аж⿻,-aнm, -amop, -ep).

The morphonological structure of word-forming nests is determined by the morphonological structure of the basic verb, morphonological transformations, morphonological positions, morphonological type. Elements of the verb base, which undergo changes under the influence of the initial of the formant, signal possible morphonological changes (truncation, consonant, vocal alternations, increase of suffix or root morphemes, change of stress) in the deverbative.

The nature of the action of the formant on the derivative basis depends on the phonological structure. The first stage of word formation is most actively morphologically marked, and for prefixal verbs - the second. In subsequent stages, morphological processes fade. The structure and filling of word-forming nests with verb verbs depend on the word-forming meanings formed by the lexical-word-forming group of creative verbs and the word-forming means, origin, frequency of verb use.

Thus, the nature of the implementation and regularity of morphonological phenomena in word formation during the creation of deverbatives are influenced by structural and phonemic properties, characteristics of creative bases and word-forming affixes, features of the contact zone on the morpheme seam (final basis and suffix initials), stress position, truncation, number of warehouses.

\section{Morphonological classifications of indivisible closed Ukrainian verb bases}

The range of variation of the creative basis can be determined taking into account phonemic and grammatical factors. Depending on the final consonant of the creative basis, there are different types of closed bases: 1) closed types of bases, which create conditions for alternating hardness - softness; 2) bases with one - soft option; 3) bases ending in sonorous; 4) verb bases ending in labial; 5) verb bases ending in $\kappa, \boldsymbol{x}$ and pharyngeal 2 . 
Morphonological means inform about the formal properties of morphemes combined in the derivational act, features of the contact zone, the constituent organization of the creative basis, the type of accent position, to differentiate the formation from specific and borrowed verbs: лежати - ліг-в(о); абстрагува́ти - абстра́к-иіј (a), претендувати прете́нз'-ij(a).

The specificity of morphological alternations, in contrast to phonemic, in hardness - softness, that it can be three-membered, because this alternation involves even and odd in hardness - softness units hissing or consonant combination: вести - водити, водіння, вождь.

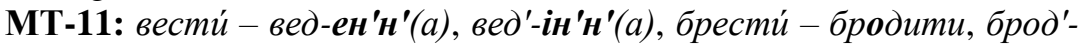
ін'н'(a),; МТ-12: пря'сти - пряд'-ін'н'(a); МТ-13: мести́ - мет'-іль,

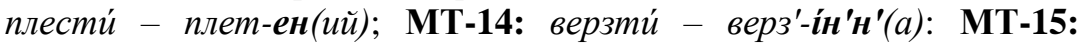

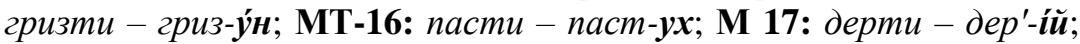
М 18: гребти́ - скреб-о́к; М-19: ску́бти - ску́ба-н'н'(a); МТ-20: могти - мож-лив(ий); МТ-21: бігти - біж-енець; стригти стриж-ен(ий); МТ-22: бігти - біж-енець; стригти - стрижен(ий); МТ-23: волокти - волочити - волоч-і́н'н'(a); МТ-24: ректи - річ-0, сікти - січ-0, січчен (ий); текти - тік-0, теч-0(a); MT-25: рости - picm-0.

The root bases of the infinitive are an ancient and morphologically complex layer of verb bases, which are divided into closed (вести, нести, лізти, пекти, текти) and open (дати, ді́/mи ${ }^{2}$ (put), мати, жати, бра́ти, жити, пити). Their common feature is that when creating deverbatives, the infinitive suffix is truncated $\boldsymbol{- m} \boldsymbol{u}$, consonant and vocal alternations, change of stress, for open - also increase of root or suffix morphemes (прибут-ок, пит-ець, паст-ух, бри-тв (a)).

Morphonological characteristics of the derivative store information about the structural and semantic rearrangements of specific and foreign language bases and the influence on them of the inventory of derivational means inherent in the corresponding word-forming unit. Morphonological modeling of deverbatives of a certain synchronous section will achieve the goal provided that possible morphonological transformations of derivatives are taken into account, allomorphs are established in a certain microsystem; under such conditions, synchrony reflects the dynamics of the system - diachrony. The description of the morphonology of word-forming units contributes to the study of the derivational potential of basic verbs, morphonological transformations at all stages of word formation and within word-forming zones, identification of morphonological models of deverbatives of substantive, 
verbal, adjectival and adverbial zones, establishment of national paraphrases. Complex morphonological operations (covering two or more types of morphonological operations) predominate in the creation of deverbatives of the substantive and adjectival zones.

Thus, the specificity of the morphonological structure of deverbatives of morphonological type is determined by the morphonological operation of truncation of the verb base, which interacts with consonant and vocal alternations, which mark the structure of deverbatives independently or in interaction with the change of accent position. In the second stage of derivation, the morphonological truncation operation usually interacts with consonantal and vocal alternations and changes in emphasis in the creation of verb derivatives: замести́ - замет'-íль (с//т'), мim-л(á) (e//i). The morphonological originality of word-forming units depends on the morphonological characteristics of the final basic verbs.

\section{Morphonological classifications of divisible Ukrainian verb bases}

All divisible verb bases are open. Divisible verb bases in the Ukrainian language during the adaptation of the verb base to the formant undergo truncation, alternation of consonants in the root morpheme. The word-forming ability of verb specific and foreign-language verb formations is influenced by their functional and stylistic characteristics: in common-language verbs the word-forming zones of the word-forming paradigm are filled differently: it is mainly four or three word-forming zones: (ход/и́/mu (591 derivative) - хо́ж-ува-ти -хож-а́й, , хо́джен(ий), дохі́-лив(ий) - дохі́лив-ість, дохідлив-о, приходити прихід-0, прихож-а́нин.

Consonant alternations in the finals of the verb base of the basic verb accompany the processes of word formation, prediction, prediction and information about morphonological positions, transformations. The morphonological type makes it possible to predict the type of consonant alternatives, morphonological phenomena in morphonologically marked deverbatives, to differentiate lexical homonyms: $\boldsymbol{c} \boldsymbol{л} / \mathbf{a} / \mathbf{m u} \boldsymbol{u}^{I}(113)$ (direct):

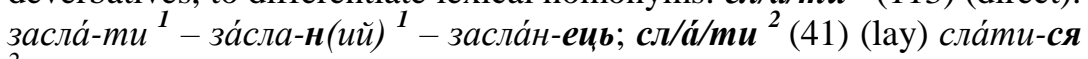
${ }^{2}$ - сла-нк(и́ŭ), сла-нь-0. Modifications of the creative basis before the formant prepare to expose the information that will be expressed by the deverbative, in particular morphonological transformations, wordforming meaning.

Analysis of the basic verbs of word-forming units revealed the following patterns: 1) consonant alternations are predictable, regular, informative; 2) morphonological transformations occur according to 
certain rules; 3) the degree of regularity, productivity, predictability of consonant alternatives in verb derivatives is different. For the contact zone on the border of root and word-forming morphemes it is necessary to take into account the following parameters: 1) the organization of the root morpheme; 2) the nature of the initial formant. Word-forming units with basic verbs are divided into 12 morphonological classes on the basis of morphonological transformation, which marks the morphonological structure of derivatives of the word-forming paradigm and determines the morphonological specificity of the class.

Thus, the ending of the creative basis and the initials of the formant determine the nature of morphonological support of word-forming processes. These patterns must be taken into account in morphonological, morpheme, word-formation, morphonological analysis and description of deverbatives in the Ukrainian language.

All word-forming units with a basic verb are divided between 12 morphonological classes, taking into account the nature of the verb base, complex morphonological transformations (consonant or vocal alternations, types of final consonant bases, character of the verb base, root or suffix morpheme increase, accent position change).

When creating derivatives from divisible verb bases, the verb ending is truncated, consonantal and vocal alternations are changed, the accent is changed. The study makes it possible to predict morphonological operations, to establish transformations of verb derivatives, to predict the morphonological structure of derivatives of word-forming units with a basic verb, taking into account the specifics of the morphonological system when creating new words (mostly complex words sometimes simple words formed by the suffix method): відроджувальник, гуглозамімення, економіковбивчий, енергоподіл, європравоохоронець, життєлов, законотворення, сіткоріз, слововиявлення, повертальник. Злетілися Пелюстки Всіх жасминів До воріт Мого раю Переметни Перецвітини Перелюбини Зима. Недострічалість (П. Поліщук) ${ }^{16}$.

The study of the peculiarities of morphonological adaptation of deverbatives in the Ukrainian language makes it possible to investigate the mechanism of base modification, morphological properties of the main body of formants, which cause morphological modifications of the

${ }^{16}$ Нелюба А., Редько С. Словотворчість незалежної України. 2012-2016 : словник / укл. А. Нелюба, С. Редько ; заг. ред. А. Нелюби. Харків : Харківське історико-філологічне товариство, 2017. 460 с. 
motivator. Elements of the verb base, which undergo changes under the influence of the initial of the formant, signal morphological changes. The morphological marking of word-forming nests depends on their wordforming potential. The study makes it possible to clarify and predict morphological operations, to establish transformations of deverbatives, to predict the morphological structure of derivatives of word-forming nests with a verb verb when creating new words.

Thus, the spectrum of morphological types of verb verbs of wordforming units in the Ukrainian language is quite capacious, it covers word-forming units of morphonological types of indivisible and divisible basic verbs of word-forming units. With indivisible apical verbs 5 morphonological classes, with divisible apical verbs -7 . With indivisible apical verbs - 25 morphonological types, with indivisible apical verbs -47 . The surveyed vertices of word-forming units of verb derivatives are characterized by different categorical-derivational potential of morphonologically marked deverbatives. Analyzing the basic verbs of word-forming units in the Ukrainian language, it is appropriate to take into account the indivisibility and divisibility of basic verbs, the final formative basis, variability/non-variability of verb bases, initial formant, morphonological transformations, positions, presence/absence of restrictions in formant compatibility.

Thus, the end of the morphonological structure of the creative basis and the initials of the formant determine the nature of the morphonological support of word-forming processes. The morphonological structure of word-forming units is determined by the morphonological structure of the basic verb, morphonological transformations, positions, class, type, model. The nature of implementation, the regularity of morphonological phenomena in the creation of deverbatives are influenced by structural and phonemic properties, characteristics of creative bases and word-forming affixes, features of the contact zone on the morpheme seam, change of emphasis, truncation, number of syllables.

\section{CONCLUSIONS}

Thus, closed bases have such different variants of creative bases when creating derivatives of verbal, substantive, adjective, adverbial blocks in a word-forming nest. Verbal bases can be open or closed. Indivisible verb bases are characterized by open (MT-1 - MT-11) and closed (MT-12 - MT-25) verb bases, divisible verb bases are characterized by open (MT-1 - MT-47) verb bases. For articulated verb 
bases, the open structure of the suffix $(\mathrm{V}, \mathrm{VCV})$ is typical, open or closed-open (CV). Word-forming units with basic verbs are divided into morphonological types on the basis of morphonological transformation, which marks the morphonological structure of derivatives of the word-forming paradigm and determines the morphonological specificity of the type.

Thus, analyzing the basic verbs of word-forming units in the Ukrainian language, it is appropriate to take into account the indivisibility and divisibility of verb verbs, the final formative basis, variability/non-variability of basic bases, formant initials, morphonological transformations, positions, presence/absence of restrictions in forman compatibility. The specificity of each morphonological type is determined by the nature of the final verb base, by morphonological transformations in morphonologically marked derivatives in the word-forming unit. Elements of the verb base, which undergo changes under the influence of the initial of the formant, signal morphonological changes. The conducted research makes it possible to elucidate morphonological operations, to establish transformations of deverbatives, to predict the morphonological structure of derivatives of word-forming units with a basic verb in the formation of new words. We see the prospect of further research of word-forming morphonology of deverbatives in the definition of morphonological types within morphonological classes.

\section{SUMMARY}

The article describes the morphonological structure of word-forming units with indivisible and divisible bases verbs is clarified in the article and the morphonological types and properties of bases verbs of wordforming units in the Ukrainian language are determined. The purpose of the article is to establish morphonological types of basic verbs of wordforming units with indivisible and divisible verb bases. The morphonological structure of word-forming units is determined by the structure of the apical verb, morphonological transformations, morphonological positions, morphonological type. The ending of the verb base, which undergoes changes under the influence of the initial of the formant, signalize morphonological transformations.

All word-forming units with an inarticulate verb are divited among 25 morphonological types, with an indivisible verb is divided between 47 morphonological types, notice the character of the verb base, complex morphonological transformations (consonant or vocal alternations, types 
of final consonant base), open, closed), increase of radical or suffix morpheme, change of accent positions. Morphonologically marked deverbatives of substantive, adjectival, verbative, adverbial blocks are analyzed.

The character of realization and regularity of morphonological phenomena in word formation during the formation of deverbatives are influenced by structural and phonemic properties, characteristics of creative bases and word-forming affixes, features of the contact zone on the morpheme seam, truncation, number of syllables. Indivisible verb bases are characterized by open and closed verb bases, divisible verb bases are characterized only by open verb bases. For articulated verb bases, the open structure of the suffix $(\mathrm{V}, \mathrm{VCV})$ is typical, open or cover-open $(\mathrm{CV})$.

Analyzing the bases verbs of word-forming units in the Ukrainian language, it is appropriate to take into count the indivisibility and divisibility of bases verbs, the final formative basis, variability/nonvariability of verb bases, morphonological transformations, morphonological positions, presence/absence of constraints in compatibility. Morphonologically marked deverbatives of substantive, adjectival, verbative, adverbial blocks are analyzed.

\section{References}

1. Антипов А.Г. Морфонологическая категоризация словообразовательной формы : автореф. дисс. ... докт. филол. наук : 10.02.01; 10.02.19. Кемерово, 2002. 56 с.

2. Данилина Н.И. Морфонологические системы в синхронии и диахронии (на материале неблизкородственных языков) : автореф. дис. ... докт. филол. наук : 10.02.19. Саратов, 2012. 38 с.

3. Демешко I.M. Морфонологічні класи словотвірних гнізд із нечленованими вершинними дієсловами в українській мові. Наукові записки. Серія «Філологічні науки». Кропивницький : КОД, 2020. Вип. 187. С. 115-121.

4. Демешко I.M. Морфонологічні класи словотвірних гнізд із членованими вершинними дієсловами в українській мові. Філологічний часопис : збірник наук. праць / гол. ред. О.Ю. Зелінська. Умань : ВПЦ «Візаві», 2020. Вип. 1 (15). С. 38-44.

5. Дияк О.В. Структурно-семантична організація словотвірних гнізд із коренями на позначення металів : автореф. дис. ... канд. філол. наук : 10.02.01. Київ, 2006. 21 с. 
6. Жарко С.Ю., Шпітько I.M. Структурно-семантичні особливості словотвірного гнізда 3 вершинним словом «море»в російській, українській і словацькій мовах. Актуальні проблеми слов'янської філологї̈. 2011. Вип. ХХІV. Ч. 1. С. 475-483.

7. Кукушкина О.В. Морфонология современного русского литературного языка : учебник. Москва : Изд-во Московского ун-та, $2016.337 \mathrm{c}$.

8. Нелюба А., Редько Є. Словотворчість незалежної України. 2012-2016 : словник / укл. А. Нелюба, С. Редько ; заг. ред. А. Нелюби. Харків : Харківське історико-філологічне товариство, 2017. $460 \mathrm{c}$.

9. Пономаренко В.Д., Дудка О.О. Структурно-семантична характеристика словотвірного гнізда 3 вершиною «Зима». Лінгвістичні дослідження : збірник наук. праць ХНПУ ім. Г.С. Сковороди. 2018. Вип. 48. С. 126-137.

10.Пристай Г.В. Динамічні морфонологічні моделі відприкметникового словотворення : автореф. дис. ... канд. філол. наук : 10.02.01. Івано-Франківськ, 2011. 20 с.

11.Русаченко Н.П. Морфонологічні процеси у словозміні та словотворі староукраїнської мови другої половини XVI-XVIII ст. : автореф. дис. ... канд. філол. наук : 10.02.01. Київ, 2004. 20 с.

12. Федурко М. Ю. Морфонологія відіменникового словотворення в сучасній українській мові : автореф. дис. ... докт. філол. наук : 10.02.01. Київ, 2005. 36 с.

13. Щигло Л.В. Словотвірний потенціал дієслівних основ 3 категоріальним значенням активного руху в сучасній німецькій мові : автореф. дис. ... канд. філол. наук : 10.02.04. Харків, 2009. 22 c.

\section{Information about the author:} Demeshko Inna Mykolaivna,

Candidate of Philological Sciences (PhD), Associate Professor at the Ukrainian Language Department Volodymyr Vynnychenko Central Ukrainian

State Pedagogical University 1, Shevchenko str., Kropyvnytskyi, 25006, Ukraine 